\title{
Comparative study on laser brazing of austenitic and martensitic stainless steels with silver-based filler metal
}

\author{
A. Khorram ${ }^{1}$, M. Ghoreishi ${ }^{1 *}$, M. J. Torkamany ${ }^{2}$, H. Rahimi ${ }^{3}$ \\ ${ }^{1}$ Department of Mechanical Engineering, K. N. Toosi University of Technology, P.O. Box 19395-1999, Tehran, Iran \\ ${ }^{2}$ Iranian National Center for Laser Science and Technology (INLC), P.O. Box 14665-576, Tehran, Iran \\ ${ }^{3}$ Oil Engine Turbine Company, Tehran, Iran
}

Received 9 March 2014, received in revised form 22 May 2014, accepted 28 May 2014

\begin{abstract}
In the present study, laser brazing of austenitic stainless steel (type 321) and martensitic stainless steel (type 410) have been performed using $400 \mathrm{~W}$ pulsed Nd:YAG laser with silverbased filler metal. The microstructure was investigated using Scanning Electron Microscopy (SEM) and Energy Dispersive X-Ray Spectroscopy (EDS). The laser brazed joints consist of $\alpha$-Ag solid solution, $\alpha^{\prime}$-Cu solid solution surrounded by the $\alpha$-Ag solid solution and eutectic structure. Filler metal shows better spreading on 321 stainless steel because of more content of $\mathrm{Ni}$ and presence of $\mathrm{Ti}$ as an activator in the alloy. The average thickness of reaction layer is approximately $3.2 \mu \mathrm{m}$ for 321 stainless steel and $2.2 \mu \mathrm{m}$ for 410 stainless steel. The tensile strength of 321 stainless steel joints is higher than that of 410 stainless steel joints due to higher thickness of reaction layer, more spreading and smaller wetting angle. The average of micro hardness for joints in a seam is approximately $146 \mathrm{HV}$.
\end{abstract}

K e y w or d s: plaser brazing, 321 stainless steel, 410 stainless steel, silver-based filler metal, pulsed Nd:YAG laser

\section{Introduction}

The term "stainless steels" describes a wide variety of chromium-containing iron-based alloys (at least $10.5 \%$ chromium) used primarily in applications demanding heat or corrosion resistance. Chromium as a unique alloy in stainless steels forms a passive layer on the steel surface which provides protection against grain boundary corrosion. There are basically five types of stainless steels: austenitic (e.g., 321), martensitic (e.g., 410), ferritic, duplex, and precipitation hardening steels $[1-3]$.

Brazing is often used to join similar and dissimilar stainless steels. A wide variety of filler metals are available commercially for the brazing of stainless steel including silver, nickel, copper and gold. In most applications, filler metals are selected on the basis of their mechanical properties, corrosion resistance, service temperature, and compatibility with the base metal. Silver brazing filler metals, specifically the BAg group, are widely used as filler metals in the brazing of stainless steels [3$5]$.

Ming Jiang et al. [6] investigated laser welding-brazing of dissimilar AZ31B magnesium $(\mathrm{Mg})$ alloy and AISI304 stainless steel using a high power fiber laser. The mechanical properties of stainless steel and titanium brazed joints with silver filler metal were studied by Winiowski [7]. Zhang et al. [8] investigated vacuum furnace brazing of $\mathrm{TiC}$ cermets/steel with Ag-31Cu-23Zn brazing alloy and Ag-54Cu-33Zn brazing alloy. Wu et al. [9] studied joining of inconel $\mathrm{X}-750$ to stainless steel 304 by induction brazing by nickel-based brazing $\mathrm{BNi}-2$ as filler metal. The effects of joining time on the microstructures of joint and base materials, elemental distribution within the brazed joint, and the joint shear strength were investigated by them. Coaxial control of aluminum and steel laser brazing processes has been studied by Frank et al. [10]. Elrefaey et al. [11] carried out vacuum furnace brazing to join steel to titanium using a silver-based filler metal. They studied correlation of the mi-

*Corresponding author: tel.: +98 2188674841 8; fax: +98 2188677274 ; e-mail address: ghoreishi@kntu.ac.ir 
Ta ble 1. Chemical composition of stainless steel type 321

\begin{tabular}{lccccccccccc}
\hline Elements & $\mathrm{C}$ & $\mathrm{Mn}$ & $\mathrm{Si}$ & $\mathrm{P}$ & $\mathrm{S}$ & $\mathrm{Cr}$ & $\mathrm{Ni}$ & $\mathrm{Mo}$ & $\mathrm{Ti}$ & $\mathrm{Cu}$ & $\mathrm{Fe}$ \\
\hline (wt.\%) & 0.06 & 1.52 & 0.62 & 0.028 & 0.02 & 17 & 9.65 & 0.21 & 0.65 & 0.21 & balance \\
\hline
\end{tabular}

Ta b le 2. Chemical composition of stainless steel type 410

\begin{tabular}{lcccccccccccc}
\hline Elements & $\mathrm{C}$ & $\mathrm{Mn}$ & $\mathrm{Si}$ & $\mathrm{P}$ & $\mathrm{S}$ & $\mathrm{Cr}$ & $\mathrm{Ni}$ & $\mathrm{Mo}$ & $\mathrm{Al}$ & $\mathrm{Cu}$ & $\mathrm{Sn}$ & $\mathrm{Fe}$ \\
\hline (wt.\%) & 0.15 & 0.31 & 0.4 & 0.006 & 0.009 & 12.57 & 0.09 & 0.02 & 0.01 & 0.04 & 0.02 & balance \\
\hline
\end{tabular}

crostructure, mechanical properties and brazing temperature of steel to titanium brazed joint simultaneously. Roy et al. [12] developed a copper-based filler alloy by arc melting of $\mathrm{Cu}, \mathrm{Mn}$ and $\mathrm{Ni}$ under argon atmosphere and casting into an ingot for 304 brazing stainless steels. Soltani Tashiet et al. [13] used vacuum brazing to join Ti-6Al-4V and austenitic stainless steel (316L) using Ag-Cu-Zn filler metal. Miao et al. [14] investigated the effect of laser offsets on joint performance of laser penetration brazing. They used $\mathrm{CO}_{2}$ laser with maximum power $3.0 \mathrm{~kW}$ for joining magnesium alloy and steel. Guoqing et al. [15] used electron beam welding with maximum electron beam gun power of 60 $\mathrm{kW}$, acceleration voltage of $60 \mathrm{kV}$ and beam current intensity that could be adjusted from 0 to $1000 \mathrm{~mA}$ for welding-brazing of WC-Co hard alloy to a steel with $\mathrm{Ni}-\mathrm{Fe}$ intermediate. Steward et al. [16] studied furnace brazing of stainless steel (304) to vanadium alloy (V-5Cr-5Ti) with pure copper filler metal. Laser brazing of a steel/aluminum assembly with hot filler wire $(88 \% \mathrm{Al}, 12 \% \mathrm{Si})$ was studied by Mathieu et al. [17]. They used a continuous-wave Nd:YAG laser with maximum power of $3.5 \mathrm{~kW}$ for this investigation. Kozlova et al. [18] investigated the wetting of stainless steels by $\mathrm{Cu}$-Ag-based alloys in high vacuum at $800-900^{\circ} \mathrm{C}$. The process variables in their experiments were the steel type, composition of the $\mathrm{Cu}-\mathrm{Ag}$-based alloy, and furnace atmosphere. Brazing of a nitrogen-containing duplex stainless steel sheet (10 $\mathrm{mm}$ thick) using a nickel-based filler metal was performed by Yuan et al. [19]. Zhanga et al. [20] studied lap joints of aluminum alloy (2B50) and stainless steel (1Cr18Ni9Ti), which were welded by MIG welding-brazing method with 4043 $\mathrm{Al}-\mathrm{Si}$ filler metal. They investigated the effect of aluminizing coating and galvanized zinc coating on fusion metal spread ability. Liu et al. [21] brazed partially stabilized zirconium to stainless steel by vacuum brazing with $\mathrm{Ag}-\mathrm{Cu}$ filler metal and $\mathrm{TiH} 2$ powder. The effects of brazing temperature and holding time on the joint shear strength were also investigated by them. Ungers et al. [22] proposed a procedure to estimate machine parameters during the process and control the quality of the process for laser brazing application.
Table 3. Chemical composition of filler metal

\begin{tabular}{lllll}
\hline Elements & $\mathrm{Ag}$ & $\mathrm{Cu}$ & $\mathrm{Zn}$ & $\mathrm{Sn}$ \\
\hline (wt.\%) & 57 & 22 & 16.5 & 4.5 \\
\hline
\end{tabular}

Li et al. [23] compared microstructure and mechanical properties of $\mathrm{Mg} / \mathrm{mild}$ steel and $\mathrm{Mg} /$ stainless steel joints that were laser welded-brazed with $\mathrm{Mg}$ -based filler metal. Their experiments were accomplished with a $3 \mathrm{~kW} \mathrm{CO}$ laser with a wavelength of $10.6 \mu \mathrm{m}$. Janssen et al. [24] studied the fatigue life time properties of laser-brazed dual phase (DP600) and transformation induced plasticity (TRIP700) steel joints made with a copper-aluminum consumable filler metal. Dharmendra et al. [25] used a CW Nd:YAG laser for lap joining of zinc coated steel (DP600) to aluminum alloy (AA6016) using a zinc-based filler wire $(85 \% \mathrm{Zn}$ and $15 \% \mathrm{Al})$. They performed LWB with varying laser power, brazing speed, and wire feed speed.

The current study attempts to characterize: 1 . the spreading and wetting of the silver-based filler metal on 321 stainless steel and 410 stainless steel in laser brazing process, 2. microstructure and mechanical properties of the laser brazed joints.

\section{Experimental procedures}

\subsection{Materials and preparation of specimens}

Austenitic stainless steel (type 321) and martensitic stainless steel (type 410 ) sheet (1 mm thick) were used as the base metal. A silver-based wire with a diameter of $1 \mathrm{~mm}$ (solidus, liquid temperature and brazing range at 618,652 and $652-760{ }^{\circ} \mathrm{C}$, respectively) was used as filler metal. Their chemical compositions (weight percent) are shown in Tables 1-3.

The stainless steel sheets were cut with dimensions of $120 \mathrm{~mm}$ long $\times 25 \mathrm{~mm}$ wide. One side of the samples was ground to provide a groove to flow the melted filler metal. The high quantities of chromium 


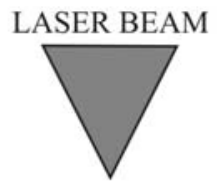

(a)

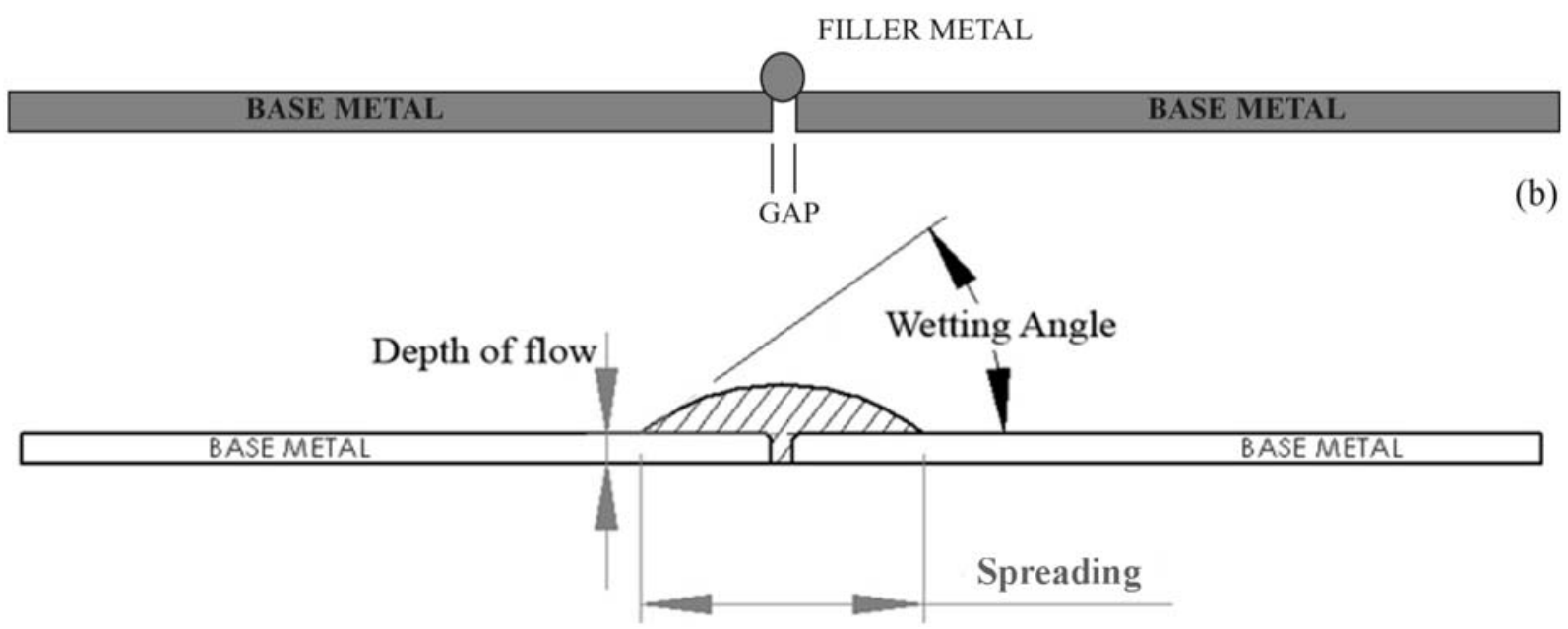

Fig. 1. Schematic geometry of laser brazing: a) before laser brazing with filler wire, b) after laser brazing.

presented in stainless steels make the chromium oxide films on the surfaces of all stainless steels, as well as the films of titanium oxide that is formed on the surfaces of titanium-stabilized stainless steels, such as type 321 . If these oxides, which are both refractory and strongly adherent, are removed inadequately, they prevent the molten filler metal from wetting the base metal, so restrain a capillary joint being formed between the joint metals [4]. Finally, samples will be degreased with acetone in an ultrasonic bath for 60 min prior brazing to prevent the entry of pollutions.

\subsection{Laser brazing processing}

The laser source was a square standard pulse wave Nd:YAG pumped by lamps, with a maximum mean laser power of $400 \mathrm{~W}$. The laser parameters can be adjusted between $1-1000 \mathrm{~Hz}$ for pulse frequency, 0.2 $20 \mathrm{~ms}$ for pulse duration, and $0-40 \mathrm{~J}$ for pulse. The lens with $75 \mathrm{~mm}$ focal length and $250 \mathrm{~mm}$ minimum spot size were used as focusing optical system. Joints between these materials were produced by laser brazing process in butt configuration with schematic geometry given in Fig. 1. The filler wire was placed on the surface of work piece prior performing the experiments. The laser brazing process was conducted under $205.2 \mathrm{~W}$ power, $1.7 \mathrm{~ms}$ pulse width, $100 \mathrm{~Hz}$ pulse frequency, $350{ }^{\circ} \mathrm{C}$ preheating and $1.8 \mathrm{~mm} \mathrm{~s}^{-1}$ travelling speed that were concluded as best setting parameters with silver-based filler metal in our previous work [26]. The laser beam was focused on the filler wire and irradiated vertically. Argon as shielding gas at a flow rate of $30 \mathrm{lmin}^{-1}$ was used to protect the molten pool.

\subsection{Characterization techniques}

After laser brazing, metallographic and hardness specimens of cross-section were cut perpendicular to the travel direction and polished by metallographic sandpapers of $240,400,600,800$, and $1000 \mathrm{SiC}$ grades. A solution $\left(1 \mathrm{~g} \mathrm{CrO}_{3}+1 \mathrm{ml} \mathrm{H}_{2} \mathrm{SO}_{4}+500 \mathrm{ml}\right.$ deionized $\mathrm{H}_{2} \mathrm{O}$ ) was used to etch the metallographic specimens to reveal the general microstructure of the laser brazed joints. The etching time per sample was approximately between $20-30 \mathrm{~s}$. The metallographic observations were conducted using an OLYMPUS stereoscope, and microstructure observations were carried out by Scanning Electron Microscope (SEM), Energy Dispersive Spectrometer (EDS). In order to identify the phases formed in the brazed joint, XRD analysis was carried out with $\mathrm{CuK} \alpha$ as $\mathrm{X}$-ray source. Tensile tests were done to evaluate the joint strength of the samples by universal testing machine with a crosshead speed of $1 \mathrm{~mm} \mathrm{~min}^{-1}$. Micro hardness tests were conducted using a Vickers micro hardness tester with a load of $100 \mathrm{~g}$.

\section{Results and discussion}

\subsection{Wettability and joints geometry}

The experiments were carried out several times at power of $205.2 \mathrm{~W}$, pulse width of $1.7 \mathrm{~ms}$, speed of $1.8 \mathrm{~mm} \mathrm{~s}^{-1}$ to confirm the repeatability of results. Figures 2,3 show the cross section of laser brazed samples for 321 stainless steel and 410 stainless steel, respect- 

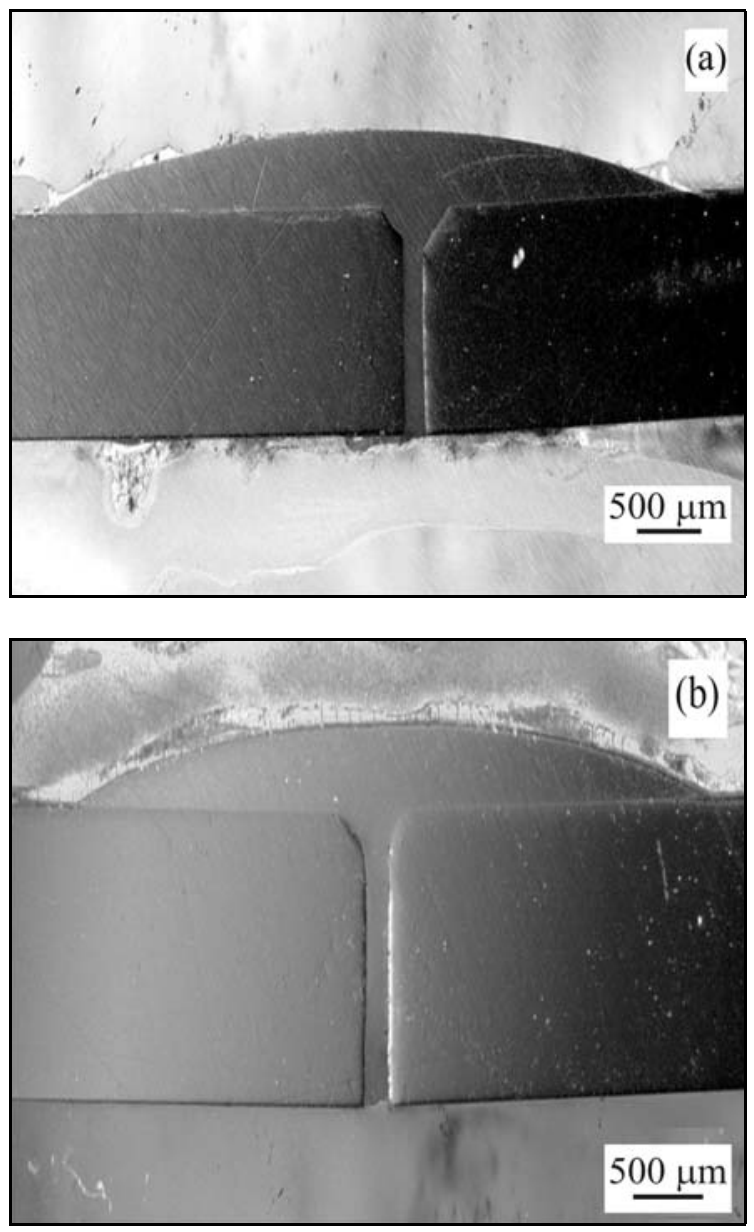

Fig. 2 a,b. Typical cross section of laser brazed samples for 321 stainless steel made in the same setting (power of $205.2 \mathrm{~W}$, pulse width of $1.7 \mathrm{~ms}$, speed of $\left.1.8 \mathrm{~mm} \mathrm{~s}^{-1}\right)$.

ively. From these figures, it can be concluded that the filler metal exhibits better wettability and spreading on 321 stainless steel than 410 stainless steel. Liquid flow into joints will occur if the filler metal wets the base metals. The average wetting angle and spreading for 321 stainless steel are 16 degree and $4200 \mu \mathrm{m}$, while the average wetting angle and spreading for 410 stainless steel are 24 degree and $3000 \mu \mathrm{m}$. Also, it shows that the joint interfaces are sound and no defects appear at the interfaces and the brazing seam. The better wetting angle and spreading of filler metal on type 321 stainless steel can be attributed to higher content of $\mathrm{Ni}$ and presence of $\mathrm{Ti}$ as an activator in this alloy. Phase diagram shows the $\mathrm{Ag}-\mathrm{Cu}-\mathrm{Ti}$ system contains a large liquid immiscibility region and the maximum solubility of $\mathrm{Ti}$ in the liquid eutectic is about $2 \%$, so good wetting is achieved for 321 stainless steel [27].

\subsection{Microstructure of the laser brazed joints}

Figure 4 shows the microstructures of the brazed
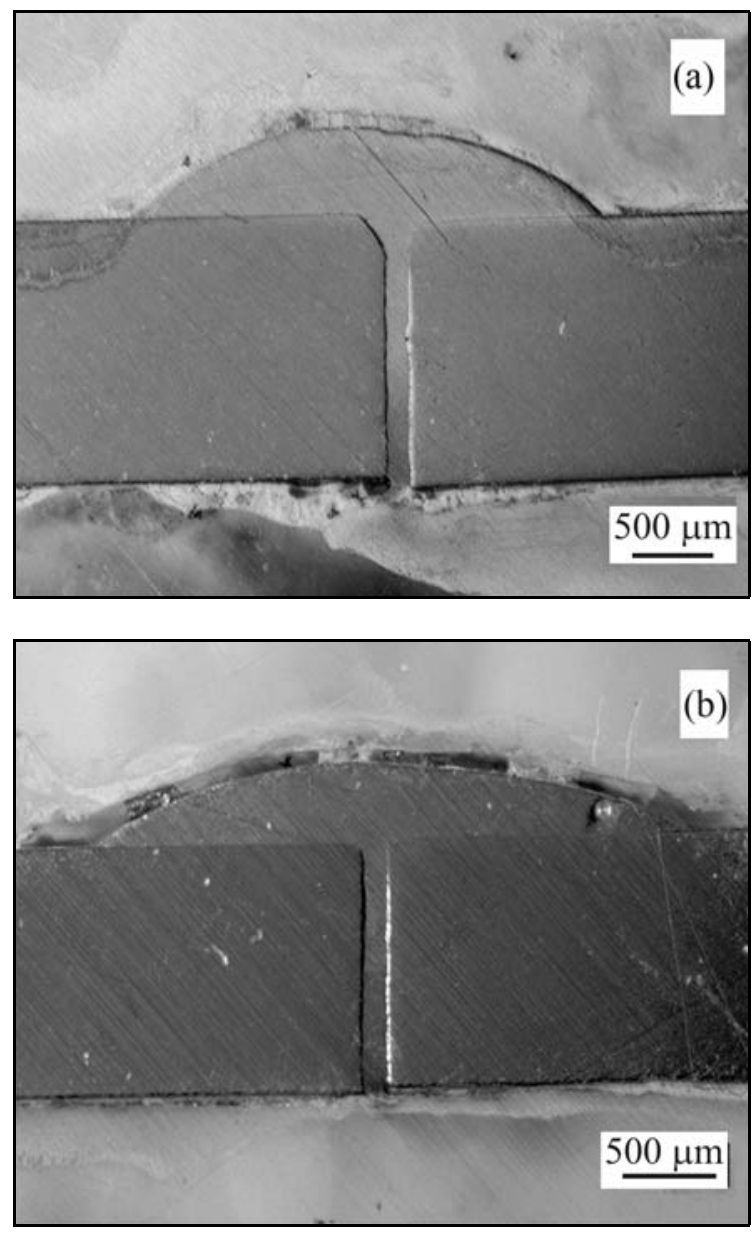

Fig. 3 a,b. Typical cross section of laser brazed samples for 410 stainless steel made in the same setting (power of $205.2 \mathrm{~W}$, pulse width of $1.7 \mathrm{~ms}$, speed of $\left.1.8 \mathrm{~mm} \mathrm{~s}^{-1}\right)$.

joints at power of $205.2 \mathrm{~W}$, pulse width of $1.7 \mathrm{~ms}$, speed of $1.8 \mathrm{~mm} \mathrm{~s}^{-1}$. The brazing seams present "as-cast microstructures" due to the "heating, melting and cooling crystallization" effects or very rapid thermal cycles during the laser brazing. As mentioned in Table 3, the dominant chemical composition of the filler metal is silver, so it is predicted that the structure of brazed joint is comprised of silver.

Figures 5 and 6 show SEM and EDS chemical analysis results of laser brazed joints at power of $205.2 \mathrm{~W}$, pulse width of $1.7 \mathrm{~ms}$, speed of $1.8 \mathrm{~mm} \mathrm{~s}^{-1}$ for 410 stainless steel and 321 stainless steel, respectively. It is clear to see in the figures that four zones have occurred named by A, B, C, and D. It can be seen from Fig. 5 that there are much $\mathrm{Ag}$ and a little $\mathrm{Cu}$, Sn and $\mathrm{Zn}$ in $\mathrm{B}$ zone. So, according to $\mathrm{Ag}-\mathrm{Cu}, \mathrm{Ag}-\mathrm{Sn}, \mathrm{Ag}-\mathrm{Zn}$ phase alloy diagrams [27], $\mathrm{Ag}$ solid solution phase exists in this zone. $\mathrm{C}$ zone has been enriched from $\mathrm{Cu}$, so probably $\mathrm{Cu}$ solid solution exists according to $\mathrm{Cu}-\mathrm{Ag}, \mathrm{Cu}-\mathrm{Sn}$, $\mathrm{Cu}-\mathrm{Zn}$ phase alloy diagrams [27]. Eutectic phases are 

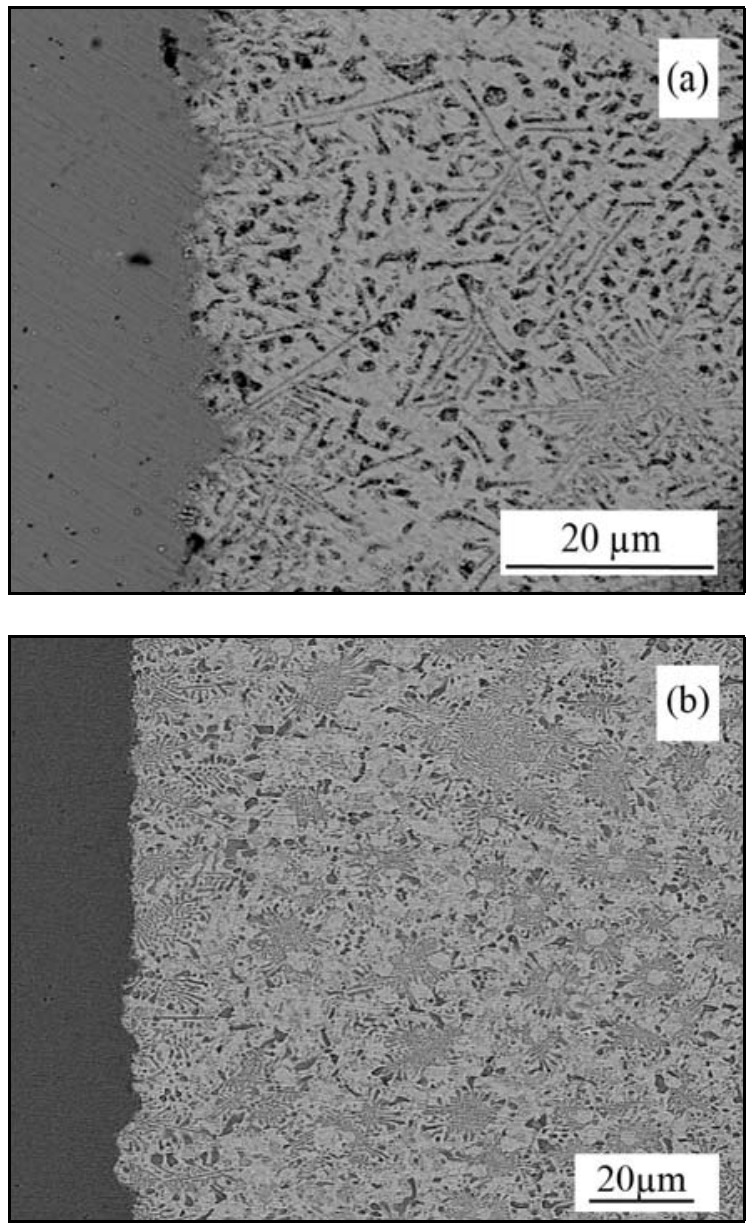

Fig. 4. SEM microstructures of laser brazed joints for a) 321 stainless steel, b) 410 stainless steel made at power of $205.2 \mathrm{~W}$, pulse width of $1.7 \mathrm{~ms}$, speed of $1.8 \mathrm{~mm} \mathrm{~s}^{-1}$.

also observed in brazed joint as marked by $\mathrm{D}$ in Fig. 5.

However, the concentration of eutectic phase could not be accurately measured by EDS analysis because of difficulties in quantifying them with sufficient accuracy. So, XRD was used to determine the phases in brazing seam. The brazing seams have silver solid solution $(\alpha-\mathrm{Ag})$, copper solid solution $\left(\alpha^{\prime}-\mathrm{Cu}\right), \mathrm{AgZn}$, $\mathrm{Ag}_{3} \mathrm{Sn}, \mathrm{Cu}_{41} \mathrm{Sn}_{11}, \mathrm{Cu}_{5} \mathrm{Zn}_{8}, \mathrm{Cu}_{6} \mathrm{Sn}_{5}$ phases, as seen in Fig. 7. It can be concluded that the laser brazed seams are primarily comprised of Ag solid solution matrix, $\mathrm{Cu}$ solid solution and small amount of eutectic phase.

The stainless steel is partially dissolved into molten filler metal, so the molten filler metal closed to stainless steel is rich in $\mathrm{Ni}, \mathrm{Fe}$ and $\mathrm{Cr}$. According to binary alloy phase diagrams, silver can alloy with $\mathrm{Ni}$, $\mathrm{Fe}$, and form a solid solution. Also, $\mathrm{Cu}$ can alloy with $\mathrm{Ni}, \mathrm{Fe}$ and $\mathrm{Cr}$ and forms a solid solution. As mentioned earlier, there is a rapid thermal cycle during laser brazing process, so dissolution of substrate is limited. The reaction layer is marked by $\mathrm{A}$ and mainly consists of

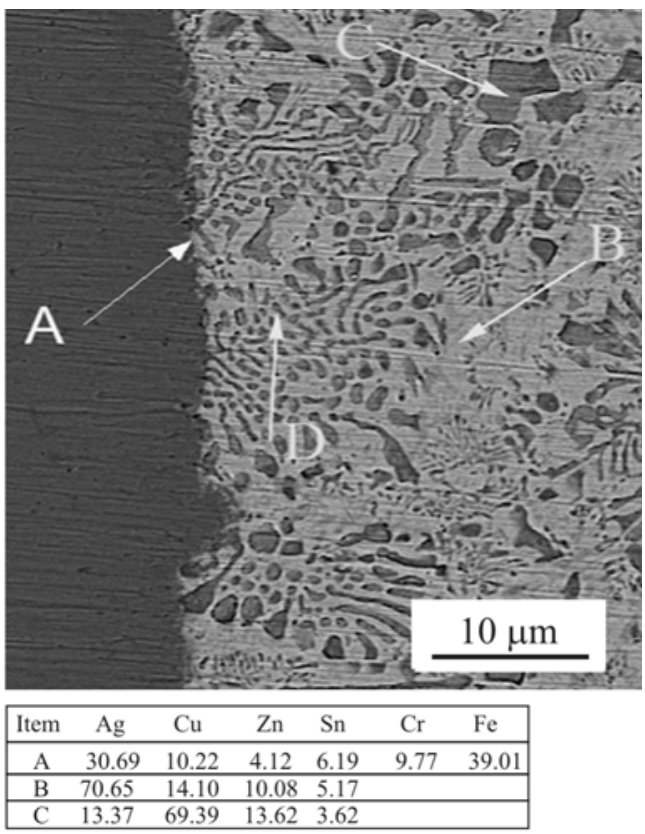

Fig. 5. SEM and EDS chemical analysis results of the laser brazed sample for 410 stainless steel made at power of $205.2 \mathrm{~W}$, pulse width of $1.7 \mathrm{~ms}$, speed of $1.8 \mathrm{~mm} \mathrm{~s}^{-1}$.

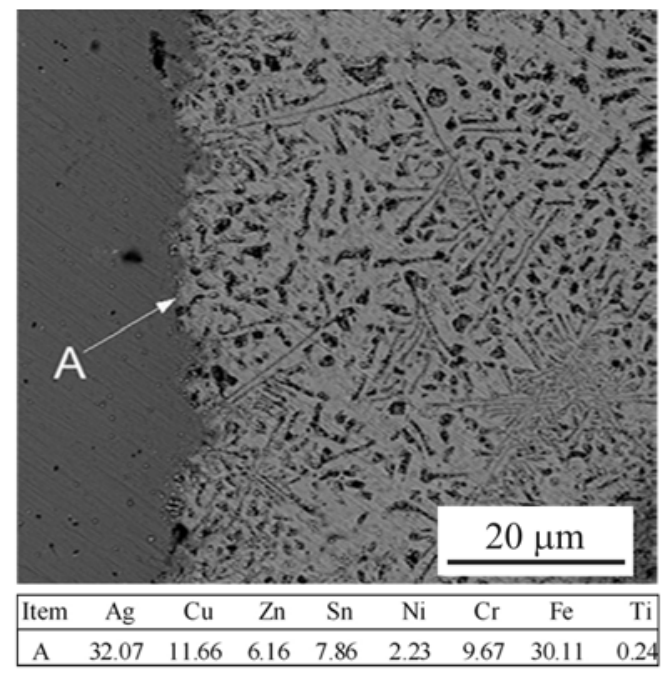

Fig. 6. SEM and EDS chemical analysis results of the laser brazed sample for 321 stainless steel made at power of $205.2 \mathrm{~W}$, pulse width of $1.7 \mathrm{~ms}$, speed of $1.8 \mathrm{~mm} \mathrm{~s}^{-1}$.

$\mathrm{Ag}, \mathrm{Cu}, \mathrm{Cr}$, and $\mathrm{Fe}$ for 321 and 410 stainless steel. Silver content in this layer is higher than the other elements. This phenomenon can be attributed to the short time of the process and more silver content in initial filler metal. The average thickness of continuous reaction layer is approximately $3.2 \mu \mathrm{m}$ for 321 stainless steel and $2.2 \mu \mathrm{m}$ for of 410 stainless steel. This indicates that the atoms diffuse in spite of short reaction time and the fast thermal cycle. 


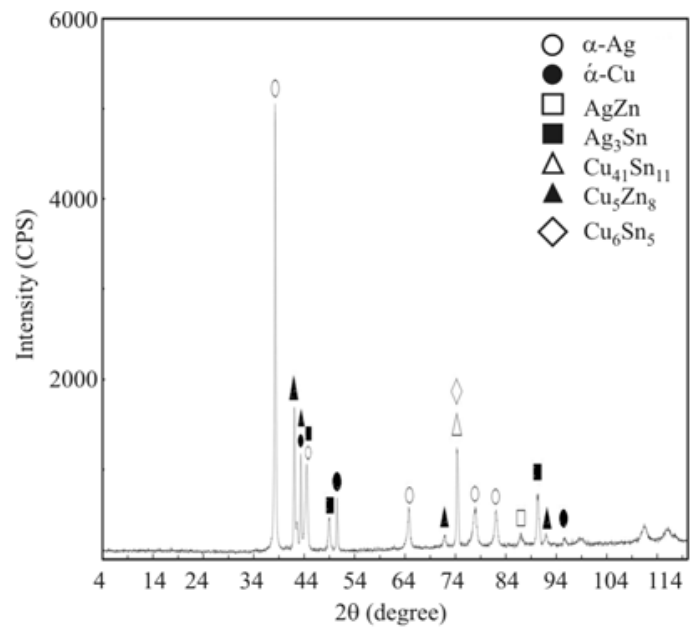

Fig. 7. XRD patterns for laser brazed joint.

Figure 8 illustrates the SEM images of the interfacial region of silver-based filler metal/321 stainless steel joint and silver-based filler metal/410 stainless steel joint, joints made at power of $205.2 \mathrm{~W}$, pulse width of $1.7 \mathrm{~ms}$, speed of $1.8 \mathrm{~mm} \mathrm{~s}^{-1}$, respectively. The profiles of various elements concentration of the laser brazed joints across the interface between the seam and the steel were obtained from EDS line scan indicated in Fig. 8 and the results are shown in Fig. 9. During this process, inter diffusion between the filler metal and the base metal can occur. From the element concentrations profile of the brazing joint in Fig. 8, it can be seen that there was gradual decrease in the $\mathrm{Ni}, \mathrm{Fe}$, and $\mathrm{Cr}$ contents for 321 stainless steel, gradual decrease in the $\mathrm{Fe}$ and $\mathrm{Cr}$ contents for 410 stainless steel and gradual increase in the $\mathrm{Ag}, \mathrm{Cu}, \mathrm{Sn}$, and $\mathrm{Zn}$ contents when the location was transited from the base metal to the filler metal. Therefore, these gradual
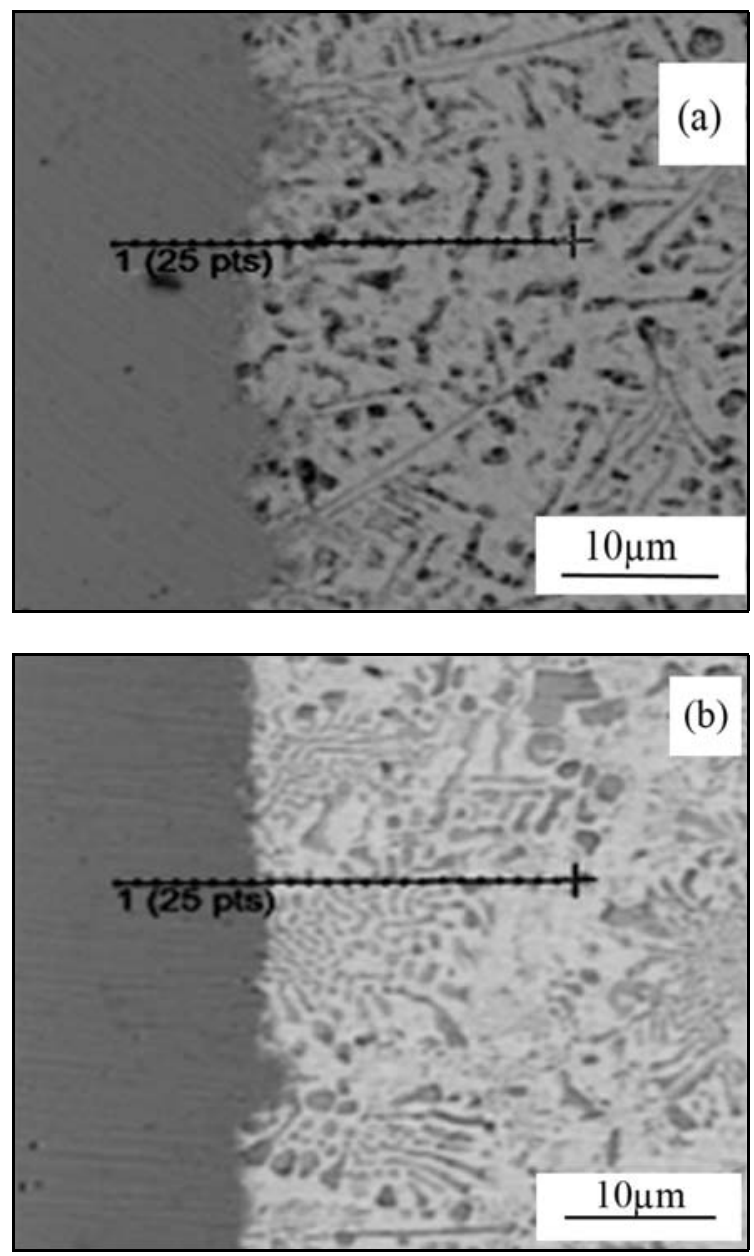

Fig. 8. SEM micrograph of silver-based filler metal/stainless steel interface made at power of $205.2 \mathrm{~W}$, pulse width of $1.7 \mathrm{~ms}$, speed of $1.8 \mathrm{~mm} \mathrm{~s}^{-1}$ : a) 321 stainless steel, b) 410 stainless steel.
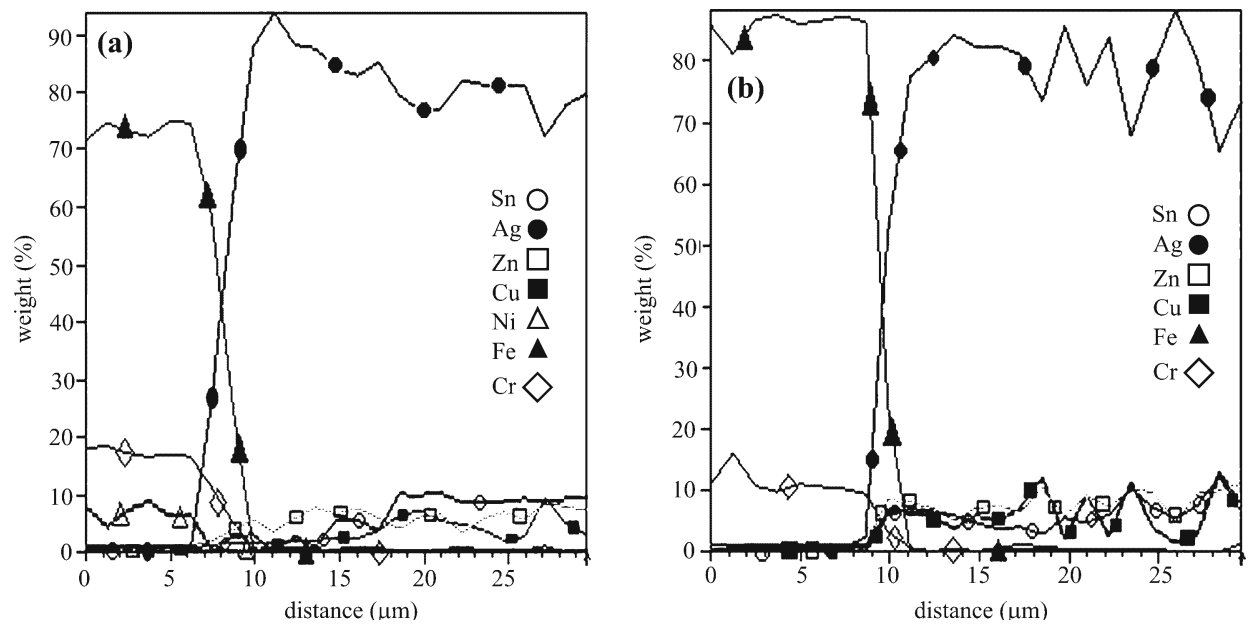

Fig. 9. EDS line scan results of the interface obtained along the arrow in Fig. 8: a) silver-based filler metal/321 stainless steel, b) silver-based filler metal/410 stainless steel. 

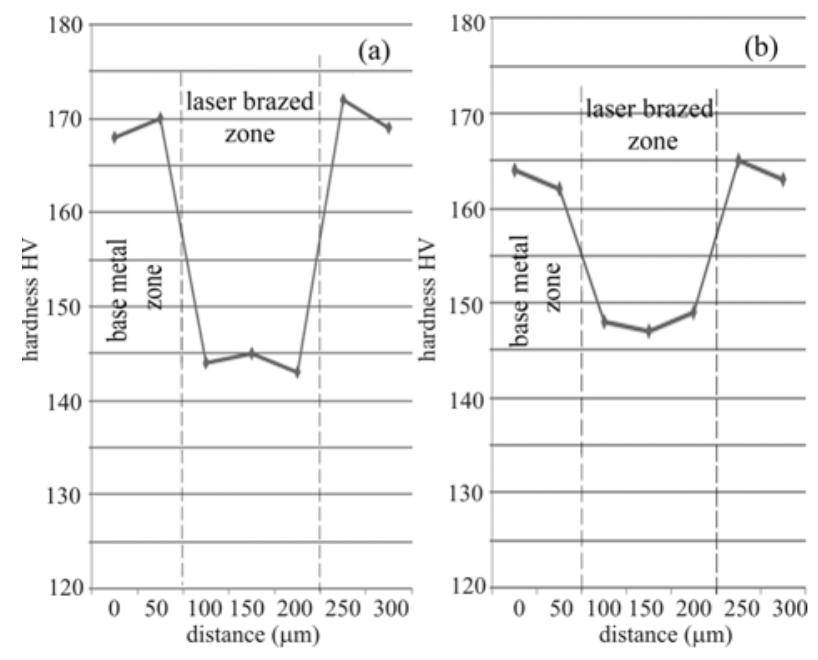

Fig. 10. Microhardness profile of laser brazed sample: a) 321 stainless steel, b) 410 stainless steel made at power of $205.21 \mathrm{~W}$, pulse width of $1.7 \mathrm{~ms}$, speed of $1.8 \mathrm{~mm} \mathrm{~s}^{-1}$.

Ta b le 4. Tensile strength of laser brazing samples

\begin{tabular}{lcc}
\hline Sample No. & $\begin{array}{c}\text { Tensile strength } \\
(\mathrm{MPa})\end{array}$ & $\begin{array}{c}\text { Elongation } \\
(\%)\end{array}$ \\
\hline Stainless steel type 321 & 340 & 9 \\
Stainless steel type 410 & 337 & 8.9 \\
\hline
\end{tabular}

curves reveal that there is inter diffusion in the interface. In other words, $\mathrm{Ag}, \mathrm{Cu}, \mathrm{Zn}, \mathrm{Sn}$ diffuse from the filler wire to the base metal and it is alloyed with a small amount of the base metal. Also, Ni, Cr, Fe diffuse from the base metal to the filler metal for 321 stainless steel, and $\mathrm{Cr}, \mathrm{Fe}$ diffuse from the base metal to the filler metal for 410 stainless steel.

\subsection{Mechanical properties of laser brazed joints}

Hardness profile and tensile test are good indicators of bond microstructure and can be used to investigate the mechanical properties. Vickers micro hardness profiles as a function of distance at power of $205.2 \mathrm{~W}$, pulse width of $1.7 \mathrm{~ms}$, speed of $1.8 \mathrm{~mm} \mathrm{~s}^{-1}$ for 321 stainless steel and 410 stainless steel are shown in Fig. 10. The average of micro hardness in seam is approximately $146 \mathrm{HV}$. The average of micro hardness for 321 stainless steel and 410 stainless steel is $170 \mathrm{HV}$ and $164 \mathrm{HV}$, respectively.

The average of tensile strength for 321 stainless steel and 410 stainless steel laser brazed joints is listed in Table 4 . The highest tensile strength could be achieved for 321 stainless steel laser brazed joints.
The thickness of reaction layer, the spreading on the substrate, and the wetting angle affect the tensile strength significantly when the gap is filled by molten filler metal. Consequently, this higher value of tensile strength can be attributed to higher thickness of reaction layer, more spreading and less wetting angle for 321 stainless steel laser brazed joints. According to binary and ternary phase diagrams [27-29], formation of inter metallic compound is not seen in the reaction layer. Therefore, increasing this layer leads to stronger joints due to better inter diffusion.

\section{Conclusions}

In this study, laser brazing of two types of stainless steels (type 321 and type 410) using silver-based filler metal has been studied. Microstructure and mechanical properties of these joints were comparatively investigated. The main conclusions of the study can be drawn as follows:

1. The suitable process parameters for austenitic and martensitic stainless steels laser brazed joints include: power of $205.21 \mathrm{~W}$, pulse width of $1.7 \mathrm{~ms}$, speed of $1.8 \mathrm{~mm} \mathrm{~s}^{-1}$, pulse frequency of $100 \mathrm{~Hz}$ and preheating of $350^{\circ} \mathrm{C}$.

2. The better wettability of filler metal on 321 stainless steel substrate than on 410 stainless steel substrate can be attributed to higher content of $\mathrm{Ni}$ and presence of $\mathrm{Ti}$ as an activator in this alloy.

3 . The average thickness value of reaction layer for 321 stainless steel is approximately $3.2 \mu \mathrm{m}$, while it is approximately $2.2 \mu \mathrm{m}$ for 410 stainless steel.

4. The average tensile strength value of 321 stainless steel laser brazed joints is higher than of 410 stainless steel laser brazed joints, while the average of micro hardness in the seam for both is approximately $146 \mathrm{HV}$.

5 . The microstructure of laser brazed joints consists of $\alpha$-Ag solid solution, $\alpha^{\prime}$-Cu solid solution surrounded by $\alpha$-Ag solid solution and eutectic structure.

\section{References}

[1] Kutz, M. (ed.): Handbook of Materials Selection. New York, John Wiley \& Sons 2002. doi:10.1002/9780470172551

[2] Farrar, J. C. M.: The Alloy Tree: A Guide to LowAlloy Steels, Stainless Steels and Nickel-Base Alloys. Boca Raton, CRC Press 2004.

[3] AWS Committee on Brazing and Soldering: Brazing Handbook. Florida, American Welding Society 2002.

[4] ASM Handbook Committee: ASM Handbook, Welding, Brazing, and Soldering. Materials Park, ASM International 1993.

[5] Schwartz Mel, M.: Brazing. Ohio, ASM International 2003. 
[6] Jiang, M., Gao, M., Li, G., Zhang, C., Zeng, X.: Kovove Mater., 52, 2014, p. 50.

[7] Winiowski, A.: Kovove Mater., 51, 2013, p. 19. doi:10.1016/j.matdes.2013.03.073

[8] Zhang, L., Feng, J., Zhang, B., Jing, X.: Mater. Lett., 59, 2005, p. 110. doi:10.1016/j.matlet.2004.08.029

[9] Wu, X., Chandeli, R. S., Pheow, S. H., Li, H.: Mater. Sci. Eng. A, 288, 2000, p. 84. doi:10.1016/S0921-5093(00)00839-X

[10] Franka, S., Ungers, M., Rolser, R.: Physics Procedia, 12, 2011, p. 752. doi:10.1016/j.phpro.2011.03.094

[11] Elrefaey, A., Tillmann, W.: J. Alloys. Compd, 487, 2009, p. 639. doi:10.1016/j.jallcom.2009.08.029

[12] Roy, R. K., Panda, A. K., Das, S. K., Govind, Mitra, A.: Mater. Sci. Eng. A, 5230, 2009, p. 312. doi:10.1016/j.msea.2009.05.049

[13] Soltani Tashi, R., Akbari Mousavi, S. A. A., Mazar Atabaki, M.: Mater. Des, 54, 2014, p. 161. doi:10.1016/j.matdes.2013.07.103

[14] Miao, Y., Han, D., Yao, J., Li, F.: Mater. Des., 31, 2010, p. 3121. doi:10.1016/j.matdes.2009.12.035

[15] Guoqing, C., Binggang, Z., Zhenzhong, W., Wei, M., Jicai, F.: Int. J. Refract. Metal. Hard Mater, 40, 2013, p. 58. doi:10.1016/j.ijrmhm.2013.03.002

[16] Steward, R. V., Grossbeck, M. L., Chin, B. A., Aglan, H. A., Gan, Y.: J. Nucl. Mater, 283-287, 2000, p. 1224. doi:10.1016/S0022-3115(00)00390-1

[17] Mathieu, A., Pontevicci, S., Claude Viala, J., Cicala, E., Matte, S., Greve, D.: Mater. Sci. Eng. A, 435436, 2006, p. 19. doi:10.1016/j.msea.2006.07.099

[18] Kozlova, O., Voytovych, R., Devismes, M. F., Eustathopoulos, N.: Mater. Sci. Eng. A, 495, 2008, p. 96. doi:10.1016/i.msea.2007.10.101
[19] Yuan, X., Yun Kang, C., Bok Kim, M.: Mater. Charact, 60, 2009, p. 923.

doi:10.1016/j.matchar.2009.03.004

[20] Zhanga, H., Liua, J.: Mater. Sci. Eng. A, 528, 2011, p. 6179 .

[21] Liu, G. W., Qiao, G. J., Wang, H. J., Yang, J. F., Lu, T. J.: J. Eur. Ceram. Soc., 28, 2008, p. 2701. doi:10.1016/j.jeurceramsoc.2008.04.008

[22] Ungers, M., Rolser, R., Abels, P.: Physics Procedia, 41, 2013, p. 524. doi:10.1016/j.phpro.2013.03.111

[23] Li, L., Tan, C., Chen, Y., Guo, W., Song, F.: Mater. Des, 43, 2013, p. 59. doi:10.1016/j.matdes.2012.06.057

[24] Janssen, M. H. E., Hermans, M. J. M., Janssen, M., Richardson, I. M.: Mater. Des., 31, 2010, p. 3922. doi:10.1016/j.matdes.2010.03.018

[25] Dharmendra, C., Rao, K. P., Wilden, J., Reich, S.: Mater. Sci. Eng. A, 528, 2011, p. 1497. doi:10.1016/j.msea.2010.10.050

[26] Khorram, A., Ghoreishi, M., Torkamany, M. J., Bali, M. M.: Optics. Laser. Technol., 56, 2014, p. 443. doi:10.1016/j.optlastec.2013.08.022

[27] ASM international Handbook Committee: ASM Handbook. Alloy phase diagrams. Materials Park, ASM International 1998.

[28] Ivanchenko, V., Leo Lukas, H.: Ternary Alloy Systems Phase Diagrams. Crystallographic and Thermodynamic Data. Volume 11. Subvolume B. Heidelberg, Springer-Verlag 2007. doi:10.1007/b96200

[29] Kubaschewski, O.: Ternary Alloy Systems Phase Diagrams, Crystallographic and Thermodynamic Data. Volume 11. Subvolume C. Heidelberg, Springer-Verlag 2007. doi:10.1007/978-3-540-47004-5 